\section{The case for child health}

\author{
Neena Modi
}

There is unlikely to be anyone in the world who would not be supportive of good health for children. Yet, child health is struggling. A year ago, the UK Royal College of Paediatrics and Child Health $(\mathrm{RCPCH})$ published 'State of Child Health'. ${ }^{1}$ We found nearly one in five children in the UK to be living in poverty and troubling disparity between the health of children in the UK and many similar nations in Europe. A year on and the $\mathrm{RCPCH}$ has issued a series of scorecards, showing what change there has been in the nations of the UK. ${ }^{2}$ Individual nations, chiefly Scotland and Wales, have made commendable progress. However, what emerges is a picture of piecemeal policy, not the astute, visionary, integrated strategy so sorely needed. Current UK metrics remain stark; child mortality is higher than in many comparable countries $^{1}$; about a third of 10 -year-old children are overweight or obese ${ }^{3}$; a quarter of 5 -year-olds have tooth decay $^{4}$; selfharm among girls aged $13-16$ has risen by two-thirds in the last 3 years $^{5}$; compared with 2015-2016, there has been a decrease in 2016-2017 in coverage of four of the six routine vaccinations at age 1 and 2 years, and coverage for Measles, Mumps and Rubella decreased for the third year in a row, following previous annual increases over 9 years. ${ }^{6}$ Child poverty is at its highest since 2010 and compared with the overall population, children are more likely to be living in a low-income household.?

Poor child health has very serious wider implications. Over $80 \%$ of obese children will remain obese as they grow older, and this will lead to them losing about 15-20 healthy-life years as adults. ${ }^{8}$ Teenagers, even if only at the upper end of normal body weight, have a substantially increased risk of premature death in adulthood. ${ }^{9}$ Air pollution experienced in fetal life, infancy and early childhood scars lungs for life, increasing the likelihood of chronic respiratory conditions in old age. ${ }^{10}$ Adverse childhood experiences increase the risk of health-harming behaviours and non-communicable diseases in later life. ${ }^{11}$ These are classic examples of societies fouling their own nests, by failing to see the

Correspondence to Professor Neena Modi, Department of Medicine, Section of Neonatal Medicine, Imperial College London, London SW7 2AZ, UK; n.modi@imperial.ac.uk destructive consequences for everyone of not safeguarding child health. The moral case for better child health is self-evident, as is that vested in self-interest, but these aside, there is a powerful economic case too. Governments need populations that are healthy, economically active and not crippled by chronic illness in old age. This means placing health foremost, especially during early development when life-long trajectories of well-being are set.

Wilkinson and Pickett use a succinct phrase in their landmark book 'The Spirit Level', 'Inequality seems to make countries socially dysfunctional across a range of outcomes'. ${ }^{12}$ Regardless of whether the cause of the position in which the UK finds itself is the placing of short-term economic growth before population well-being, or a reluctance to acknowledge the long-term consequences of short-term policies, this appears to be what we are witnessing today. It need not be so. The insights of science can form the basis of a strategy to improve child health, in full recognition that this will improve the health of the adult population, and so too the economic prosperity of the nation. Governments recognise the need for a healthy economy; incubators and accelerators to boost new enterprises spring forth like mushrooms; isn't it time the impact of good child health on the economy merited equal investment? Shouldn't nations view good child health as essential as roads, railways and a power supply? To underline the message that we all benefit from 'giving every child the best start in life', Michael Marmot's famous policy objective in 'Fair society, healthy lives', ${ }^{13}$ I suggest there is need to link several concepts.

The first is that health has determinants that extend beyond diagnosing and treating disease. This is now widely accepted as the diverse range of social, economic and environmental factors that affect health and which are influenced by national and international policies. Many studies have estimated that the contributions of these wider determinants to population health are greater than healthcare, lifestyle choices or genetic endowment. ${ }^{14}$ Several commentators have also highlighted the likely economic costs of failing to act on the wider determinants of health, ${ }^{13}$ while acknowledging that better data on economic returns would be helpful ${ }^{15}$ as would be the expertise of economists in measuring health not healthcare activity as the outcome of each investment. RCPCH therefore applauds Public Health England for its championing of a 'health in all policies' approach ${ }^{16}$ but is disappointed that the intended audience does not include central Government. If the message of the wider determinants of health is to be taken seriously, there can be no escaping the conclusion that health impact must be a fundamental consideration of every national policy.

That there are strong consistent associations between poverty, deprivation and poor health is undeniable, but effective policies are built on understanding of causal pathways. For many years, proponents of policies aimed at reducing health inequalities were constrained in making their case because evidence of causality was limited. This is no longer so. Science is unravelling causal mechanisms that lead from poverty to poor health, providing unsurpassed opportunity to prevent or attenuate aberrant health trajectories. For example, children living in poverty are at greater risk of exposure to environmental and nutritional pollutants and toxins than those from backgrounds that are more affluent. They are also more likely to encounter adverse childhood experiences that result in epigenetic reprogramming of life-long mechanisms of health and disease. ${ }^{11}$ Similarly, it is now clear that maternal obesity is a toxic insult to the developing fetus; yet, over half of all pregnant women in the UK are now overweight or obese. ${ }^{17}$ This is fuelling a rise in gestational diabetes and increasing the risks of congenital anomalies, stillbirth and prematurity. The children of mothers with gestational diabetes are also about six times more likely to develop diabetes, ${ }^{18}$ independent of genetic predisposition, placing a new generation firmly on a trajectory of compromised health. This is the science of the developmental origins of health and disease.

Knowledge such as this can be translated into policy. For example, reducing air pollution would have immediate positive health impact and the case for a policy of population-wide folate supplementation is now overwhelming. Though innumerable interventions to achieve weight loss during pregnancy have shown little success, the UK Government's 2016 policy document 'Childhood Obesity: A Plan for Action' placed predominant reliance on voluntary action, for which it was heavily criticised. ${ }^{19}$ The vicious transgenerational cycle of obesity requires breaking earlier in the life course using multiple hard-hitting measures that involve children and 
young people themselves, as in the University of Southampton's Life Lab, ${ }^{20}$ so that they approach parenthood with healthy weight and lifestyle.

A well-functioning healthcare system is also essential to child health. The benefits of the National Health Service (NHS) have been clear; it has delivered efficient, cost-effective, equitable healthcare. Its founding principles-universal healthcare free at the point of need, funded through general taxation with Government responsible and accountable through Parliament-have been a beacon for over six decades and have been envied and admired around the world. However, following the infamous 2012 Health and Social Care Act, ${ }^{21} 22$ the NHS has been under increasingly severe pressure, despite challenge to the present direction of travel. ${ }^{23-26}$ The UK Secretary of State for Health is currently facing a legal challenge relating to the Department of Health's consultation on proposed legislation that in theory would enable conversion of the NHS into a US-style insurance-based system. $^{27}$ Treating healthcare as a commodity disadvantages everyone, the poor through limitations on access and the rich through overinvestigation and unnecessary treatment. Inequity in healthcare, such as exists in the USA, will not serve children well.

It is hard to know how the imminent departure of the UK from the European Union will affect children and children's services. However, child health is unlikely to gain if there is further reduction in the paediatric clinical and academic workforce. As with other specialities, including general practice and nursing, paediatric trainee numbers have fallen following their damaging dispute with government in 2016. Paediatricians in the UK are better trained and better skilled than ever before. Yet, they are now working within a struggling health system where the collegiality and shared sense of purpose that exemplified the NHS are being threatened by the loss of pay parity, the uncertainties of Brexit, a squeeze on pensions and a severe shortfall in funding for primary care, acute and public health services.

Another issue is the development of medicines, an area where it has long been recognised that children are served poorly by market forces. This coupled with international pressure led to the USA and the European Union to provide incentives to manufacturers to develop medicines specifically for infants and children. UK children have benefited from this legislation and from the UK being a member of the European Medicines Agency. We can only hope that this will continue postBrexit and that continued pan-European collaboration in wider research, building on the highly effective existing UK children's research network will not be placed in jeopardy.

Despite the accumulating wealth and weight of evidence justifying action to improve child health, progress remains stubbornly slow. Sadly, scientific evidence has always had to battle to make its way into policy, from clean water in the 19th century, smoking bans in the 20th century to now, in the 21st century, action to improve child health. Industry, other than the vaccine industry, has also been slow to capitalise on the preservation of health. Instead, the world has witnessed ferocious decade-long battles to curb the blight inflicted by the tobacco industry, continued damage from the junk food and fizzy drinks industries and exponential environmental pollution from the plastics and some manufacturing industries. The medicines experience shows that industry can be incentivised to do the right thing. This lesson should be applied to other areas, rewarding the preservation of health and regulating against the converse. Industry could benefit from being innovative and putting their talents towards exploiting the science of the developmental origins and wider determinants of health and disease to preserve health.

Almost a century has passed since Eglantyne Jebb, the founder of Save the Children, formulated the visionary declaration, later to be the convention on 'the rights of the child' ${ }^{28}$ Over this time, it has become evident that these rights do indeed make a difference to children's lives, but change has been slow even in mature democracies such as the UK because the citizens who elect our representatives are adults. Infants, children and young people represent almost a quarter of the population, yet because they have no vote their perspectives are inadequately represented in national policy. The health and well-being of the nation would be well served if ways could be found to ensure the voices of infants, children and young people are heard. Might this goal be realised if parents received a proxy vote for each underage child? This could be the muchneeded ground-breaking 21st century stimulus to bring child friendly policies and long-term perspectives finally to serious political attention. In the meantime, paediatricians must continue to do the best they can to advocate on behalf of all children. The RCPCH mission is to lead the way in child health. We invite organisations and individuals to join us in developing and advancing this vision.

Twitter NeenaModi@RCPCHPresident

Competing interests NM is President of the Royal College of Paediatrics and Child Health.

Provenance and peer review Commissioned; internally peer reviewed.

(c) Article author(s) (or their employer(s) unless otherwise stated in the text of the article) 2018. All rights reserved. No commercial use is permitted unless otherwise expressly granted.

\section{A) Check for updates}

To cite Modi N. Arch Dis Child 2018:103:316-318.

Received 2 January 2018

Revised 23 January 2018

Accepted 26 January 2018

Published Online First 9 February 2018

Arch Dis Child 2018;103:316-318.

doi:10.1136/archdischild-2017-314638

\section{REFERENCES}

1 Royal College of Paediatrics and Child Health. State of child health report. 2017 https://www.rcpch.ac.uk/ system/files/protected/page/SoCH\%202017\%20UK\% 20web\%20updated.pdf (accessed 18 Jan 2018).

2 Royal College of Paediatrics and Child Health. Fragmented approach to child health damaging long term health of nation warns Royal College. https:// www.rcpch.ac.uk/news/fragmented-approach-childhealth-damaging-long-term-health-nation-warnsroyal-college (accessed 23 Jan 2018).

3 NHS Digital. Statistics on obesity, physical activity and diet England. 2017 https://www.gov.uk/government/ uploads/system/uploads/attachment_data/file/613532 obes-phys-acti-diet-eng-2017-rep.pdf (accessed 18 Jan 2018).

4 Public Health England. Guidance child oral health: applying all our health. 2017 https://www.gov.uk/ government/publications/child-oral-health-applyingall-our-health/child-oral-health-applying-all-our-health (accessed 18 Jan 2018).

5 Morgan C, Webb RT, Carr MJ, et al. Incidence, clinical management, and mortality risk following self harm among children and adolescents: cohort study in primary care. BMJ 2017;359:j4351.

6 NHS Digital. Childhood vaccination coverage statistics, England 2016-17. https://digital.nhs.uk/catalogue/ PUB30085 (accessed 18 Jan 2018).

7 Department for Work and Pensions. Households below average income: an analysis of the UK income distribution: 1994/95-2015/16. https://www.gov.uk/ government/uploads/system/uploads/attachment data/file/600091/households-below-averageincome-1994-1995-2015-2016.pdf (accessed 18 Jan 2018).

8 Grover SA, Kaouache M, Rempel P, et al. Years of life lost and healthy life-years lost from diabetes and cardiovascular disease in overweight and obese people: a modelling study. Lancet Diabetes Endocrinol 2015;3:114-22

9 Twig G, Yaniv G, Levine $H$, et al. Body-mass index in 2.3 million adolescents and cardiovascular death in adulthood. N Engl J Med 2016:374:2430-40.

10 Royal College of Physicians and Royal College of Paediatrics and Child Health. Every breath we take: the lifelong impact of air pollution. 2016 file:///home/ lavanyam/Downloads/Every\%20breath $\% 20$ we $\%$ 20take.\%20Full\%20Report\%20Low\%20res._0.pdf

11 Braveman P, Gottlieb L. The social determinants of health: it's time to consider the causes of the causes. Public Health Rep 2014;129(Suppl 2):19-31. 
12 Pickett K, Wilkinson R. The spirit Level: why more equal societies almost always do better. Bloomsbury Press, 2009.

13 Strategic Review of Health Inequalities in England Post-2010. Fair society, healthy lives: the marmot review. http://www.instituteofhealthequity.org/ resources-reports/fair-society-healthy-lives-themarmot-review/fair-society-healthy-lives-full-reportpdf.pdf (accessed 18 Jan 2018).

14 Wilkinson R, Marmot M. The social determinants of health: the solid facts. 2nd edn. Europe: World Health Organisation, 2003. ISBN 9289013710.

15 Buck D, Gregory S. The Kings Fund. Improving the public's health A resource for local authorities. 2013 https://www.kingsfund.org.uk/sites/default/files/field/ field_publication_file/improving-the-publics-healthkingsfund-dec13.pdf (accessed 18 Jan 2018).

16 Public Health England. Guidance Local wellbeing, local growth: adopting health in all policies. $2016 \mathrm{https}: / /$ www.gov.uk/government/publications/local-wellbeinglocal-growth-adopting-health-in-all-policies (accessed 18 Jan 2018).
17 National Maternity and Perinatal Audit. Key findings. http://www.maternityaudit.org.uk/Audit/Charting/ Keyfindings 1516 (accessed 18 Jan 2018).

18 Garcia-Vargas L, Addison SS, Nistala R, et al. Gestational diabetes and the offspring: implications in the development of the cardiorenal metabolic syndrome in offspring. Cardiorenal Med 2012;2:134-42.

19 Knai C, Petticrew M, Mays N. The childhood obesity strategy. BMJ 2016;354:i4613.

20 University of Southampton https://www.southampton. ac.uk/lifelab/index.page (accessed 18 Jan 2018)

21 Ham C, Baird B, Gregory S, et al. The NHS under the coalition government: part one: NHS reform. 2015 https://www.kingsfund.org.uk/publications/nhs-undercoalition-government

22 Timmins N. Never again: the story of the health and social care Act 2012. The kings fund. $2012 \mathrm{https}: / /$ www.kingsfund.org.uk/sites/default/files/field/field_ publication_file/never-again-story-health-social-carenicholas-timmins-jul12.pdf (accessed 18 Jan 2018).

23 Care Quality Commission. The state of health care and adult social care in England 2016/17.
2017 https://www.cqc.org.uk/sites/default/files/ 20171123_stateofcare1617_report.pdf (accessed 18 Jan 2018)

24 Ham C. Simon Stevens speaks out over NHS funding. BMJ 2017;359:j5251.

25 BBC News. Stephen Hawking: I'm worried about the future of the NHS. http://www.bbc.co.uk/news/health40967309 (accessed 18 Jan 2018).

26 The Guardian. Richard Branson's Virgin healthcare firm scoops $\mathrm{f} 1 \mathrm{bn}$ of NHS contracts. https://www. theguardian.com/society/2017/dec/29/richardbranson-virgin-scoops-1bn-pounds-of-nhs-contracts (accessed 18 Jan 2018).

27 Independent. Jeremy Hunt faces legal action over attempts to 'Americanise' the NHS. http://www. independent.co.uk/news/uk/politics/jeremy-hunthealth-department-nhs-legal-action-americaniseprivatisation-customers-id-pay-a8033986.html (accessed 18 Jan 2018).

28 Save the Children. Our history where we started, to where we are today. https://www.savethechildren.org. uk/about-us/our-history (accessed 18 Jan 2018). 